\title{
RECENT PROGRESS IN GaInASSb THERMOPHOTOVOLTAICS GROWN BY ORGANOMETALLIC VAPOR PHASE EPITAXY
}

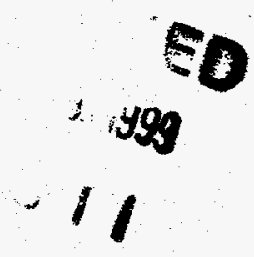

C. A. Wang, H.K. Choi, D. C. Oakley, G. W. Charache

June 1998

DASTRIBUTION OF THIS DOCUMENT IS UNLMITED \& MASTER

\section{NOTICE}

This report was prepared as an account of work sponsored by the United States Government. Neither the United States, nor the United States Department of Energy, nor any of their employees, nor any of their contractors, subcontractors, or their employees, makes any warranty, express or implied, or assumes any legal liability or responsibility for the accuracy, completeness or usefulness of any information, apparatus, product or process disclosed, or represents that its use would not infringe privately owned rights. 


\section{DISCLAMMER}

This report was prepared as an account of work sponsored by an agency of the United States Government. Neither the United States Government nor any agency thereof, nor any of their employees, makes any warranty, expras or implied, or assumes any legal liability or responsibility for the accuracy, completeress, or usefulness of any information, apparatus, product, or process disclosed, or represents that its use would not infringe privately owned rights. Reference herein to any specific commercial product, process, or service by trade name, trademark, inanufac. turer, or otherwise does not necessarily constitute or imply its endorsement, recommendation, or favoring by the United States Government or any ageacy thereof. The views and opinions of authors expressed herein do not necessarily state or reflect those of the United States Government or any agency thereof. 


\section{DISCLAIMER}

Portions of this document may be illegible in electronic image products. Images are produced from the best available original document. 
Recent Progress in GaInAsSb Thermophotovoitaics Grown by Organometallic Vapor Phase Epitaxy*

C.A. Wang ${ }^{\dagger}$, H.K. Choi, D.C. Oakley

Lincoln Laboratory, Massachusetts Institute of Technology, Lexington, MA 02173-9108

G.W. Charache

Lockheed Martin, Inc., Schenectaday, NY 12301

\section{Abstract}

Studies on the materials development of $\mathrm{Ga}_{1-x} \mathrm{In}_{\mathrm{x}} \mathrm{As} \mathrm{S}_{\mathrm{y}} \mathrm{b}_{1-\mathrm{y}}$ alloys for thermophotovoltaic (TPV) devices are reviewed. $\mathrm{Ga}_{1-x} \mathrm{In}_{x} \mathrm{As} \mathrm{s}_{\mathrm{y}} \mathrm{S}_{1-\mathrm{y}}$ epilayers were grown lattice matched to $\mathrm{GaSb}$ substrates by organometallic vapor phase epitaxy (OMVPE) using all organometallic precursors including triethylgallium, trimethylindium, tertiarybutylarsine, and trimethylantimony with diethyltellurium and dimethylzinc as the $n$ - and p-type dopants, respectively. The overall material quality of these alloys depends on growth temperature, In content, V/II ratio, substrate misorientation, and to a lesser extent, growth rate. A mirror-like surface morphology and room temperature photoluminescence (PL) are obtained for GaInAsSb layers with peak emission in the wavelength range between 2 and $2.5 \mu \mathrm{m}$. The crystal quality improves for growth temperature decreasing from 575 to $525^{\circ} \mathrm{C}$, and with decreasing In content, as based on epilayer surface morphology and low temperature PL spectra. A trend of smaller full width at halfmaximum for low temperature PL spectra is observed as the growth rate is increased from 1.5 to 2.5 and $5 \mu \mathrm{m} / \mathrm{h}$. In general, GaInAsSb layers grown on (100) $\mathrm{GaSb}$ substrates with a $6^{\circ}$ toward (111)B misorientation exhibited overall better material quality than layers grown on the more standard substrate $(100) 2^{\circ}$ toward (110). Consistent growth of high performance lattice-matched GaInAsSb TPV devices is also demonstrated.

*This work was sponsored by the Department of Energy under AF Contract No. F19628-95-C. 0002. The opinions, interpretations, conclusions and recommendations are those of the author and are not necessarily endorsed by the United States Air Force.

'Fax: 781-981-0122; e-mail: wang@ll.mil.edu. 


\section{Introduction}

Thermophotovoltaic (TPV) power generation involves the conversion of thermal energy to electrical energy through the use of photovoltaic (PV) cells. A critical factor in determining overall system efficiency is optimum utilization of radiant photons: the peak in emissive power of the thermal source should closely match the energy gap of the PV cell material, and photons with energies below semiconductor bandgap should be reflected back to the thermal emitter. The early developments of TPV systems in the 1970's mainly utilized conventional Si solar cells, which were readily available. Consequently, high emitter temperatures in excess of $2000 \mathrm{~K}$ are necessary for these cells. Unformunately, it is difficult to obtain such temperatures with conventional combustion sources, and thermal management of these high temperatures is challenging. As a result, the technology was limited and interest in TPV's declined in the 1980's.

Presently, however, there is strong renewed interest in TPV's because of recent improvements in the quality of epitaxially grown, low energy gap III-V semiconductors. Current developments of TPV systems are based on semiconductors with a cutoff wavelength range of 1.9 to $2.6 \mu \mathrm{m}$, and thermal sources that operate in the more moderate temperature range of 1100 to $1500 \mathrm{~K}$ [1]. There are several semiconductor materials systems that satisfy the energy gap requirement. For example. InGaAs grown on InP substrates has been pursued with some success. However, the alloy composition that satisfies this wavelength range is lattice mismatched to the InP substrate, and although defect-filtering schemes have been employed, the device performance is compromised by crystalline defects $[2,3]$. Similarly, InGaSb grown on GaSb substrates has shown some promise, but also is lattice mismatched [4].

Alternative low bandgap materials systems which can be lattice matched to binary substrates are GaInAsSb or InAsPSb. GaInAsSb is of particular interest for TPV's since these alloys have successfully been grown for detectors and lasers. Recently, we reported the highest performing TPV devices with a $2.3 \mu \mathrm{m}$ cutoff wavelength, internal quantum efficiency of $-90 \%$, and large open circuit voltage of $-300 \mathrm{meV}$ [5]. The epitaxial structures, which are typically 
$-5 \mu \mathrm{m}$ in thickness, were grown by both organometallic vapor phase epitaxy (OMVPE) and molecular beam epitaxy (MBE) and exhibited similar high performance. Since higher growth rates are attainable in OMVPE compared to MBE, OMVPE is especially attractive for preparation of TPV device structures.

In this paper, we review some of our recent work on OMVPE of $\mathrm{Ga}_{1 . x} \mathrm{In}_{\mathrm{x}} \mathrm{As} \mathrm{s}_{\mathrm{S}} \mathrm{Sb}_{1-\mathrm{y}}$ alloys with 2 to $2.4 \mu \mathrm{m}$ cutoff wavelength [6], and report on new results. In particular, we have increased the growth rate from 2.5 to $5 \mu \mathrm{m} / \mathrm{h}$, while also improving the overall quality of $\mathrm{Ga}_{1 \cdot x} \mathrm{In}_{\mathrm{x}} \mathrm{As}_{\mathrm{y}} \mathrm{Sb}_{1-y}$ lattice matched to GaSb. Furthermore, we have further extended room temperature photoluminescence (PL) emission to $2.5 \mu \mathrm{m}$. Low temperature PL spectra exhibit (full width at half-maximum) FWHM as nartow as $5 \mathrm{meV}$. We also report the device characteristics of recent TPV cells. The device results are remarkably consistent and exhibit near-theoretical performance limits.

\section{The $\mathrm{Ga}_{1 \cdot x} \mathrm{In}_{\mathrm{x}} \mathrm{As}_{\mathrm{S}} \mathrm{Sb}_{1-\mathrm{y}}$ quaternary alloy}

The energy gap dependence on composition of the $\mathrm{Ga}_{1-x} \mathrm{In}_{\mathrm{x}} \mathrm{As}_{\mathrm{y}} \mathrm{Sb}_{1-\mathrm{y}}$ quaternary alloy, based on the binary bandgaps [7], is given by $E(x, y)=0.726-0.961 x-0.501 y+0.08 x y+$ $0.415 x^{2}+1.2 y^{2}+0.021 x^{2} y-0.62 x y^{2}$. Although this alloy has the advantage that it can be lattice matched to either GaSb or InAs substrates, growth on GaSb substrates is perferred over InAs because of thermodynamic considerations [8] and electronic band structure [9]. For alloys lattice matched to GaSb, $y=0.867(x) /(1-0.048 x)$. Figure 1 shows the energy gap dependence on As for various In concentrations for TPV's, and the unique alloy composition for lattice matching to $\mathrm{GaSb}$ at room temperature. The energy gap is determined in large part by the In content of the alloy, while the As content mainly affects the lattice constant.

Alloys grown lattice matched to GaSb substrates have encrgy gap that is adjustable in the wavelength range of 1.7 to $4.2 \mu \mathrm{m}$. However, most of the alloy compositions are thermodynamically unstable [8]. Even so, $\mathrm{Ga}_{1-x} \mathrm{In}_{\mathrm{x}} \mathrm{As} \mathrm{Sb}_{1-\mathrm{y}}$, alloys near or within the 
miscibility gap have been successfully grown by a number of epitaxial techniques which include liquid phase epitaxy (LPE) [10], OMVPE [6,8,11-13], and MBE [14,15].

\section{Epitaxial growth and characterization}

$\mathrm{Ga}_{1 . x} \mathrm{In}_{x} \mathrm{As}_{\mathrm{s}} \mathrm{Sb}_{1-y}$ epilayers were grown in a vertical rotating-disk reactor with $\mathrm{H}_{2}$ carrier gas at a flow rate of $10 \mathrm{slpm}$, reactor pressure of 150 Torr, and a typical rotation rate of $100 \mathrm{rpm}$ [6]. Solution trimethylindium (TMIn), triethylgallium (TEGa), tertiarybutylarsine (TBAs), and trimethylantimony (TMSb) were used as organometallic precursors. The selection of these sources was based on several criteria. Since $\mathrm{Gr}_{1-x} \mathrm{In}_{\mathrm{x}} \mathrm{As} \mathrm{S}_{\mathrm{Sb}} \mathrm{b}_{1-\mathrm{y}}$ alloys have a Jow melting point, the precursors should have a low thermal decomposition temperature for mass-transport limited growth. Therefore, TEGa and TBAs are preferred over trimethlylgallium and arsine, respectively, whose pyrolysis temperatures are over $100^{\circ} \mathrm{C}$ bigher than their counterparts. We selected TMSb over triethylantimony (TESb) in spite of the higher pyrolysis temperature of TMSb because previous swdies of GaSb growth from TEGa and TESb suggested source prereactions with TESb, but not with TMSb [16]. (All sources are premixed in a single fastswitching manifold before introduction into the reactor.) TMIn and TEGa were maintained at $24^{\circ} \mathrm{C}$, TMSb at $0^{\circ} \mathrm{C}$, and TBAs at $-8^{\circ} \mathrm{C}$. For doping studies, diethyltellurium (DETe) (10 ppm in $\left.\mathrm{H}_{2}\right)$ and dimethylzinc $(\mathrm{DMZn})\left(1000 \mathrm{ppm}\right.$ in $\left.\mathrm{H}_{2}\right)$ were used as $\mathrm{n}$ - and p-type doping sources, respectively.

The total group III mole fraction ranged from 1.7 to $7.6 \times 10^{-4}$, which resulted in a growth rate of -1.5 to $5 \mu \mathrm{m} / \mathrm{h}$. The TMIn fraction in the gas phase, pTMIn $/[\mathrm{pTMln}+\mathrm{pTEOa}$, was varied from 0.09 to 0.27 and the VIII ratio from 0.9 to 1.7. For lattice matching to GaSb substrates, the TBAs fraction in the gas phase, pTBAs/[PTBAs + PTMSb], was varied from 0.05 to 0.2 . Epilayers were grown at 525,550 , and $575^{\circ} \mathrm{C}$.

$\mathrm{Ga}_{1-\mathrm{x}} \mathrm{In}_{\mathrm{x}} \mathrm{As} \mathrm{SS}_{\mathrm{1-y}}$ epilayers were grown without a $\mathrm{GaSb}$ buffer on (100) Te-doped $\mathrm{GaSb}$ substrates misoriented $2^{\circ}$ toward $(110)$ or $6^{\circ}$ toward (111)B. For electrical characterization, semi-insulating (SI) GaAs substrates of similar orientations were used because SI GaSb 
substrates are not available. Just before loading the GaSb and $\mathrm{GaAs}$ substrates into the reactor, they were degreased in solvents and acid etched. GaAs substrates were etched for $30 \mathrm{~s}$ in $5: 1: 1$ $\mathrm{H}_{2} \mathrm{SO}_{4}: \mathrm{H}_{2} \mathrm{O}_{2}: \mathrm{H}_{2} \mathrm{O}$, and rinsed in deionized water. $\mathrm{GaSb}$ substrates were first etched in concentrated $\mathrm{HCl}$ for $3 \mathrm{~min}$, followed by a 1 min etch in $\mathrm{Br}_{2}-\mathrm{HCl}-\mathrm{HNO}_{3}-\mathrm{CH}_{3} \mathrm{COOH}$, and rinsed in isopropanol. This etch yielded excellent and reproducible GaSb surfaces for epitaxy, provided that the etch solution was freshly mixed.

The surface morphology was examined using Nomarski contrast microscopy. Doublecrystal $\mathrm{x}$-ray diffraction $(\mathrm{DCXD})$ was used to measure the degree of lattice mismatch $(\triangle \mathrm{g} / \mathrm{a})$ to GaSb substrates. PL was measured at 4 and $300 \mathrm{~K}$ using a PbS detector. The In and As content of epilayers was determined from DCXD splitting, the peak emission in $300 \mathrm{~K} \mathrm{PL}$ spectra, and the energy gap dependence on composition based on the binary energy gaps. For electrical characterization, GalnAsSb was grown at 525 or $550^{\circ} \mathrm{C}$ on SI (100) GaAs substrates. Since the mismatch between GaInAsSb and GaAs is $\sim 8 \%$, a GaSb buffer layer, typically $0.4 \mu \mathrm{m}$ thick, was first grown at $550^{\circ} \mathrm{C}$ to reduce the contribution of electrically active defects due to the lattice mismatch [6]. Carrier concentration and mobility of GaInAsSb epilayers, which were grown about $3 \mu \mathrm{m}$ thick, were obtained from Hall measurements based on the van der Pauw method.

\section{Growth results}

\subsection{Alloy composition control}

As discussed above, the energy gap of $\mathrm{Ga}_{1-x} \mathrm{In}_{\mathrm{x}} \mathrm{As}_{\mathrm{y}} \mathrm{Sb}_{1-\mathrm{y}}$ is affected primarily by the $\mathrm{x}$ value, while the $\mathrm{y}$-value is used to adjust the lattice constant to match to the GaSb substrate. The distribution coefficients of In and As are summarized in Figs. $2 a$ and $2 b$, respectively. The growth temperature was 525,550 , or $575^{\circ} \mathrm{C}$; the growth rate ranged from 1.5 to $5 \mu \mathrm{m} / \mathrm{h}$; and the V/III ratio ranged between 1.1 and 1.4. Test data include those previously reported [6] as well as new data for layers grown on both $(100) 2^{\circ}$ toward $(110)$ and $(100) 6^{\circ}$ toward (111)B substrates, for layers grown at the higher growth rate of $5 \mu \mathrm{m} / \mathrm{h}$, and for layers grown at $525^{\circ} \mathrm{C}$. For all 
layers, $|\Delta a / a|<2 \times 10^{-3}$. At $525^{\circ} \mathrm{C}$, the In distribution coefficient is 1.2 , and decreases to 0.95 and 0.5 at 550 and $575^{\circ} \mathrm{C}$, respectively. The trend of a lower In distribution coefficient with increasing temperature is similar to results reported for growth using TMGa and TMIn $[8,17]$. However, in those studies, the dependence is attributed to the increase in TMGa pyrolysis with temperature. For the range of growth temperatures and reactor used in this study, it is likely that both TMIn and TEGa are completely pyrolyzed. Thus, these results may reflect a difference in In-related surface kinetics. Figure $2 b$ shows that the As distribution coefficient is approximately unity independent of growth temperature, indicating complete pyrolysis of TBAs and TMSb. In contrast, the As distribution coefficient was reported to be a strong function of temperature when TMGa, TMIn, TBAs, and TMSb were used as precursors [17].

The degree of lattice mismatch of $\mathrm{Ga}_{1-x} \mathrm{In}_{\mathrm{x}} \mathrm{As} \mathrm{s}_{\mathrm{S}} \mathrm{Sb}_{1-\mathrm{y}}$ epilayers on $\mathrm{GaSb}$ can influence the performance of minority carrier type. Therefore, we determined the sensitivity of lattice mismatch on the fraction of TBAs in the gas phase. Figure 3 shows the lattice mismatch as a function of TBAs fraction in the gas phase for various TMIn fractions and total group III mole fractions. On average, the sensitivity is about $2 \times 10^{-3} \%$ per TBAs fraction in the gas phase, and is independent of growth temperature and growth rate.

\subsection{Structural properties}

As reported previously [6], the surface morphology of $\mathrm{Ga}_{1 . x} \mathrm{In}_{\mathrm{x}} \mathrm{As}_{\mathrm{y}} \mathrm{Sb}_{1-y}$ layers depends on V/III ratio, substrate misorientation, In content, and growth temperature. Below a critical V/II ratio, which is slightly higher than 1 for the growth temperature range in this study, the $\mathrm{Ga}_{1-\mathrm{x}} \mathrm{In}_{\mathrm{x}} \mathrm{As} \mathrm{SS}_{\mathrm{1}} \mathrm{-y}$ is metal-rich and the surface is hazy to the naked eye. However, a surface texture, as observed by Nomarski contrast microscopy, developed when the V/III ratio was increased just above the minimum V/II ratio. The surface morphology of epilayers grown on (100) $2^{\circ}$ toward (110) substrates is more sensitive to growth conditions than (100) $6^{\circ}$ toward (111)B substrates, and a smoother surface morphology is observed for layers grown on substrates with a $6^{\circ}$ toward (111)B misorientation. 
The In content also affects the surface morphology. Figure 4 shows the surface morphology of $\mathrm{Ga}_{1-x} \mathrm{In}_{x} \mathrm{As}_{\mathrm{y}} \mathrm{Sb}_{1-\mathrm{y}}$ layers with various $\mathrm{In}$ concentrations. These layers were grown at $525^{\circ} \mathrm{C}$ with a growth rate of $5 \mu \mathrm{m} / \mathrm{h}$ on (100) $6^{\circ}$ toward (111)B GaSb substrates. As the In concentration increases, the surface morphology exhibits increased texture. The degradation in surface morphology is likely related to the increased instability of the alloy since the composition corresponds to regions further in the miscibility region [8]. The surface morphology of $\mathrm{Ga}_{1-\mathrm{x}} \mathrm{In}_{\mathrm{x}} \mathrm{As}_{\mathrm{y}} \mathrm{Sb}_{1 . y}$ grown under similar conditions on (100) $2^{\circ}$ toward (110) substrates (Fig. 5), however, exhibited facetted defects.

The DCXD of nominally lattice matched $\mathrm{Ga}_{1-x} \mathrm{In}_{\mathrm{x}} \mathrm{As} \mathrm{Sb}_{1 \cdot \mathrm{y}}$ epilayers also exhibited a dependence on the In concentration. Figure 6 shows DXCD scans for epilayers about $2 \mu \mathrm{m}$ in thickness. The full width at half-maximum (FWHM) of the epilayer peak is comparable to that of the GaSb substrate for In $=0.09$ (Fig. 6a). It increases with increasing In, and for In -0.20 (Fig. 6c), the layer peak is extremely broadened. This broadening may be the precursor to phase separation of the $\mathrm{Ga}_{1-x} \operatorname{In}_{\mathrm{x}} \mathrm{As} \mathrm{Sb}_{1-y}$ metastable alloy.

\subsection{Optical properties}

Figure 7 shows the 4 and $300 \mathrm{~K} \mathrm{PL}$ spectra for $\mathrm{Ga}_{1-x} \ln _{x} A s_{y} S_{b_{1-y}}$ layers of two different compositions grown at $525^{\circ} \mathrm{C}$ on (100) $\mathrm{GaSb}$ substrates with a $6^{\circ}$ toward (111)B misorientation. The layers are $-2 \mu \mathrm{m}$ in thickness, and the growth rate was $5 \mu \mathrm{m} / \mathrm{h}$. The peak emission for the sample shown in Fig. $7 \mathrm{a}(\mathrm{x}=0.16, \mathrm{y}=0.15)$ is $2080 \mathrm{~nm}$ at $4 \mathrm{~K}$ and $2320 \mathrm{~nm}$ at $300 \mathrm{~K}$. The $4 \mathrm{~K}$ FWHM is $7.5 \mathrm{meV}$. For the sample shown in Fig. $7 \mathrm{~b}(x=0.2, y=0.18)$, the peak emission is $2225 \mathrm{~nm}$ at $4 \mathrm{~K}$ and $2505 \mathrm{~nm}$ at $300 \mathrm{~K}$. The FWHM at $4 \mathrm{~K}$ increases to $25 \mathrm{meV}$ which is not surprising since this alloy penetrates further into the miscibility gap. Although lattice matched $\mathrm{Ga}_{1-x} \mathrm{In}_{\mathrm{x}} \mathrm{As}_{\mathrm{S}} \mathrm{Sb}_{1}$, y layers of higher In composition (see Fig. 4d) could be grown, this layer did not exhibit PL at 4 or $300 \mathrm{~K}$. The longest PL emission at $300 \mathrm{~K}$ observed in our current study is $2525 \mathrm{~nm}$. 
Figure 8 summarizes our best FWHM data for $\mathrm{Ga}_{a_{-x}} \mathrm{In}_{\mathrm{x}} A \mathrm{As}_{\mathrm{y}} \mathrm{Sb}_{1-\mathrm{y}}$ epilayers, which shows improvement over our previous results [6]. These layers were grown at 525 or $550^{\circ} \mathrm{C}$, and at various growth rates. Several trends are observed. The PL FWHM values are strongly dependent on growth temperature and peak energy, and weakly dependent on growth rate. The lowest PL FWHM values are obtained for layers grown at the lower temperature of $525^{\circ} \mathrm{C}$. The narrowest PL FWHM values are $\sim 5 \mathrm{meV}$ for $4 \mathrm{~K}$ peak energy greater than $0.62 \mathrm{eV}$, and increase sharply below $0.60 \mathrm{eV}$. A slight improvement in FWHM values are observed for layers grown at the higher growth rates. Since broadening in PL spectra can be a result of alloy scattering [18], the data suggest increased alloy clustering especially for layers with composition approaching the miscibility gap [8]. Our FWHM values are significantly smaller than those reported previously for OMVPE-grown layers $[8,12,17]$, especially for those layers with lower PL peak energy. The smallest FWHM value measured is $4.7 \mathrm{meV}$ at $0.643 \mathrm{cV}$. Our FWHM values are favorably comparable to those reported for layers grown by MBE [11] and by LPE [19].

For GaInAsSb alloys, PL results are usually reported at low temperature. The emission at room temperature is then estimated from these low temperature results and an interpolation based on the energy difference of the 4 and $300 \mathrm{~K}$ near-bandedge transitions for GaSb [20] and InAs [21]. However, our results shown in Fig. 9 indicate that such extrapolations can be in error. The energy difference between the 4 and $300 \mathrm{~K}$ PL is plotted as a function of the $4 \mathrm{~K}$ PL peak energy for GaInAsSb alloys grown at 525,550 , and $575^{\circ} \mathrm{C}$. For most of the GalnAsSb alloys grown at 525 or $550^{\circ} \mathrm{C}$, this energy difference ranges between 0.05 and $0.07 \mathrm{meV}$, which is in line with the difference for GaSb and InAs binaries. However, for alloys grown at $575^{\circ} \mathrm{C}$, the 4 and $300 \mathrm{~K}$ energy difference decresses from about 65 to $10 \mathrm{meV}$ as the $4 \mathrm{~K}$ PL peak energy decreases to $0.6 \mathrm{eV}$. The FWHM values also increased to about 20 to $30 \mathrm{meV}$, which suggests that the $4 \mathrm{~K}$ PL emission may be related to impurity or defect transitions. 


\subsection{Electrical properties}

The carrier concentration and mobility were measured from GaInAsSb layers grown on SI GaAs substrates because SI GaSb substrates are not available. Since the lattice mismatch between GaInAsSb (lattice matched to GaSb) and GaAs is $8 \%$, a 0.4- $\mu \mathrm{m}$-thick GaSb buffer was first grown at $550^{\circ} \mathrm{C}$ as deseribed previously [6], followed by the GaInAsSb epilayer. Nominally undoped GaInAsSb layers are p-type. The lowest residual hole concentration and highest mobility values were measured for layers grown at $550^{\circ} \mathrm{C}$. The typical hole concentration is as low as $5 \times 10^{15} \mathrm{~cm}^{-3}$ with a corresponding mobility of $430 \mathrm{~cm}^{2} / \mathrm{V}-\mathrm{s}$. Considerably higher hole concentration ( 2 to $5 \times 10^{16} \mathrm{~cm}^{-3}$ ) and lower mobility $\left(220\right.$ to $\left.320 \mathrm{~cm}^{2} / \mathrm{N}-\mathrm{s}\right)$ were recently reported for GaInAsSb grown with TMGa, TMIn, arsine, and TMSb [22]. For GalnAsSb layers grown by MBE, the hole concentration was reported to be 4 to $5 \times 10^{16} \mathrm{~cm}^{-3}$ and the mobility to be $254 \mathrm{~cm}^{2} / \mathrm{V} \cdot \mathrm{s}[23]$.

The $300 \mathrm{~K}$ electrical properties of $\mathrm{p}$ - and $\mathrm{n}$-doped $\mathrm{Ga}_{1-\mathrm{x}} \operatorname{In}_{x} \mathrm{As}_{\mathrm{y}} \mathrm{Sb}_{1-\mathrm{y}}(\mathrm{x}-0.13, \mathrm{y}-0.12)$ grown at 525 and $550^{\circ} \mathrm{C}$ are summarized in Figs. $10 \mathrm{a}$ and $10 \mathrm{~b}$, respectively. The plots include data from layers grown at a rate of either 2.5 or $5 \mu \mathrm{m} / \mathrm{h}$. Because the electrical characteristics are similar for layers grown on $(100) 2^{\circ}$ toward $(110)$ and on $(100) 6^{\circ}$ toward (111)B (not differentiated in Figs. 10a and 10b), the compensation mechanism is similar. Data plotted are for GalnAsSb grown on a 0.4 - and $0.8-\mu \mathrm{m}$-thick buffer layers. The hole concentration ranges from $4.4 \times 10^{15}$ to $1.8 \times 10^{18} \mathrm{~cm}^{-3}$ with mobility values between 560 and $180 \mathrm{~cm}^{2} / \mathrm{V}-\mathrm{s}$, respectively. The electron concentration ranges from $2.3 \times 10^{17}$ to $4.2 \times 10^{18} \mathrm{~cm}^{-3}$, with corresponding mobility values between 5208 and $2084 \mathrm{~cm}^{2} / \mathrm{V}-\mathrm{s}$, respectively. These mobility values are likely to be an underestimate of true values, since the mismatch is significant, and the procedure for the GaSb buffer layer growth has not been optimized. Although there is extremely limited data for GaInAsSb electrical properties, we believe these results are a significant improvement over resuits reported previously $[12,22,23]$. 


\section{Thermophotovoltaic Devices}

TPV device structures were grown on (100) GaSb substrates with either $2^{\circ}$ toward (110) or $6^{\circ}$ toward (111)B misorientation. The growth iemperature was 525 or $550^{\circ} \mathrm{C}$. The TPV structure consists of the following layers: $0.4-\mu m$-thick $n$-GaSb buffer layer, $1-\mu \mathrm{m}$-thick $\mathrm{n}$ -

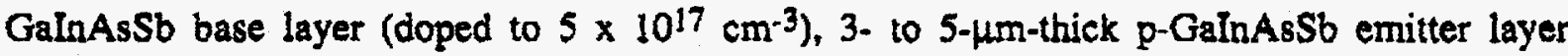
(doped to $2 \times 10^{17} \mathrm{~cm}^{-3}$ ), $0.1-\mu$ m-thick p-AlGaAsSb window layer (doped to $4 \times 10^{17} \mathrm{~cm}^{-3}$ ), and $0.05-\mu \mathrm{m}$-thick p-GaSb contact layer (doped to $2 \times 10^{18} \mathrm{~cm}^{-3}$ ), grown on a GaSb substrate. In some cases, the AJGaAsSb window layer was omitted, and a p-GaSb layer was grown as both window and contact layer.

Large-area $\left(1 \mathrm{~cm}^{2}\right)$ TPV cells were fabricated by a conventional photolithographic

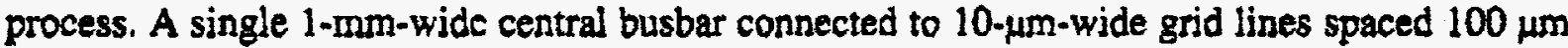
apart was used to make electrical contact to the front surface. Ohmic contacts to p-and n-GaSb were formed by depositing $\mathrm{Ti} / \mathrm{PV} / \mathrm{Au}$ and $\mathrm{Au} / \mathrm{Sr} / \mathrm{T} / \mathrm{PV} / \mathrm{Au}$, respectively, and alloying at $300^{\circ} \mathrm{C}$. Mesas were formed by wet chemical etching to a depth of $\sim 5 \mu \mathrm{m}$. No antireflection coatings were deposited on these test devices.

The external quantum efficiency (QE) of several representative TPV devices is plotted as a function of wavelength in Fig. 11. The QE is typically between 55 and $60 \%$ and has a cutoff wavelength of $2.3 \mu \mathrm{m}$. The highest QE measured is $70 \%$, which is approaching the $100 \%$ internal quantum efficiency limit if a surface reflection of $30 \%$ is assumed. The open circuit voltage $\left(V_{\infty}\right)$ as a function of short circuit current density $\left(J_{k c}\right)$ is shown in Fig. 12. At $1 \mathrm{~A} / \mathrm{cm}^{2}$, $V_{o c}$ is a high value of $300 \mathrm{meV}$. The fill factor for these devices is typically $69 \%$. Over the course of several months, we have grown and fabricated nearly $40 \mathrm{TPV}$ wafers. The average external QE is $59.3 \%$ with a standard deviation of $3.8 \%$, and only one device with external $Q E$ less than 50\% was measured. 


\section{Conclusions}

High quality GaInAsSb epilayers were grown lattice matched to GaSb substrates by OMVPE using TEGa, TMIn, TBAs, and TMSb at 525,550 , and $575^{\circ} \mathrm{C}$. Mirror-smooth surface morphology was obtained for alloys with $300 \mathrm{~K}$ PL emission in the wavelength range 2 to 2.5 $\mu \mathrm{m}$. In general, the highest material quality is observed for layers grown at the lowest temperature $525^{\circ} \mathrm{C}$, and on (100) $6^{\circ}$ toward (111)B GaSb substrates. Layer quality also shows improvement when the growth rate is increased from 2.5 to $5 \mu \mathrm{m} / \mathrm{h}$. TPV devices exhibit both high internal quantum efficiency and high $V_{o c}$. This work demonstrates that the OMVPE growth technology is extremely attractive for the synthesis of GaInAsSb materials for TPV devices.

\section{Acknowledgments}

The authors gratefully acknowledge D,R. Calawa for X-ray diffraction, J,W. Chludzinski for photoluminescence, P.M. Nitishin for technical assistance in characterization, K.J. Challberg for manuscript editing, and D.L. Spears for continued support and encouragement. 


\section{References}

1. 2nd NREL Conference on the Thermophotovoltaic Generation of Electricity, edited by J.P. Benner, T.J. Coutts, and D.S. Ginley, AIP Conference Proceedings Vol. 358, Woodbury, NY, 1995.

2. M.W. Wanlass, J.S. Ward, K.A. Emery, M.M. Al-Jassim, K.M. Jones, and T.J. Coutts, Solar Energy Mater. Solar Cells 44/42 (1996) 405.

3. S. Wojtczuk, P. Colter, G. Charache, and B. Campbell, Proc. 25th IEEE Photovoltaic Specialist Conf. (1996) 77.

4. H. Ehsani, I. Bhat, C. Hitchcock, R. Gutman, G. Charache, and M. Freeman, in 3nd NREL Conference on the Thermophotovoltaic Generation of Electricity, edited by T.J. Coutts, C.S. Allman, and J.P. Benner, AIP Conference Proceedings Vol, 401, Woodbury, NY, 1997, p. 65.

5. H.K. Choi, C.A. Wang, G.W. Turner, M.J. Manfra, D.L. Spears, G.W. Charache, L.R. Danielson, and D.M. Depoy, Appl. Phys. Lett. 71 (1997) 3758.

6. C.A. Wang, accepted J. Cryst. Growth.

7. J.C. DeWinter, M.A. Pollock, A.K. Srivastava, and J.L. Zyskind, J. Electron. Mater. 14 (1985) 729.

8. M.J. Cherng, H.R. Jen, C.A. Larsen, G.B. Stringfellow, H. Lundt, and P.C. Taylor, J. Cryst. Growth 77 (1986) 408.

9. A.G. Milnes and A.Y. Polyakov, Mater. Sci. Eng. B 18 (1993) 237.

10. E. Tournie, F. Pitard, and A. Joullie, J. Cryst. Growth 104 (1990) 683.

11. C.A. Wang, H.K. Choi, G.W. Turner. D.L. Spears, M.J. Manfra, and G.W. Charache, in 3rd NREL Conference on the Thermophotovoltaic Generation of Electricity, edited by J.P. Benner and T.J. Coutts, AIP Conference Proceedings Vol. 401, Woodbury, NY, 1997, p. 75.

12. J. Shin, T.C. Hsu, Y. Hsu, and G.B. Stringfellow, J. Cryst. Growth 179 (1997) 1.

13. A. Giani, J. Bougnot, F. Pascal-Delannoy, G. Bougnot, J. Kaoukab, G.G. Allogho, and M. Bow, Mater. Sci. Eng. B 9 (1991) 121.

14. H.K. Choi, S.J. Eglash, and G.W. Turner, Appl. Phys. Lett. 64 (1994) 2474.

15. T.H. Chui, J.L. Zyskind, and W.T. Tsang. J. Electron. Mater. 16 (1987) 57.

16. C.A. Wang, S. Salim, K.F, Jensen, and A.C. Jones, J. Cryst. Growth 170 (1997) 55. 
17. M. Sopanen, T. Koljonen, H. Lipsanen, and T. Tuomi, J. Cryst. Growth 145 (1994) 492.

18. J. Singh and K.K. Bajaj, Appl. Phys. Lett. 44 (1984) 1075.

19. E. Tournie, J.-L. Lazzari, F. Pitard, C. Alibert, A. Joullie, and B. Lambert, J. Appl. Phys. $68(1990) 5936$.

20. S.C. Chen and Y.K. Su, J. Appl. Phys. 66 (1989) 350.

21. Z.M. Fang. K.Y. Ma, D.H. Jaw, R.M. Cohen, and G.B. Stringfellow, J. Appl. Phys. 67 (1990) 7034 .

22. A. Giani, F. Pascal-Delannoy, J, Podlecki, and G. Bougnot, Mater. Sci. Eng. B 41 (1996) 201.

23. A.Z. Li, J.Q. Zhong, Y.L. Zheng, J.X. Wang, G.P. Ru, W.G. Bi, and M. Qi, J. Cryst. Growth 150 (1995) 1375. 
Figure Captions

Figure $1300 \mathrm{~K}$ energy gap dependence of $\mathrm{Ga}_{1-x} \mathrm{In}_{x} \mathrm{As}_{y} \mathrm{Sb}_{1-y}$ as a function of $\mathrm{As}$ for various In compositions.

Figure 2 Distribution coefficients of (a) In and (b) As for $\mathrm{Ga}_{1-x} \operatorname{In}_{\mathrm{x}} \mathrm{As} \mathrm{s}_{\mathrm{S}} \mathrm{Sb}_{1-\mathrm{y}}$ epilayers grown nominally lattice matched to $\mathrm{GaSb}$ at $525^{\circ} \mathrm{C}$ (open squares), $550^{\circ} \mathrm{C}$ (solid circles), and $575^{\circ} \mathrm{C}$ (open circles).

Figure 3 Lattice mismatch as a function of TBAs fraction in the gas phase for $\mathrm{Ga}_{1}$ ${ }_{x} \operatorname{In}_{x} A s_{y} S_{1-y}$ epilayers grown at $525^{\circ} \mathrm{C}$. TMIn fraction ranges from 0.09 to 0.21 .

Figure 4 Surface morphology of nominally lattice matched $\mathrm{Ga}_{1 . x} \operatorname{In}_{\mathrm{x}} \mathrm{As} \mathrm{s}_{\mathrm{S}} \mathrm{S}_{1-\mathrm{y}}$ epilayers grown at $525^{\circ} \mathrm{C}$ on (100) $6^{\circ}$ toward (111)B GaSb substrates with compositions: (a) $x=0.09, y=0.08$; (b) $x=0.16, y=0.15$; (c) $x=0.20, y=0.18$; (d) $x \sim 0.23$, $y \sim$ 0.21 The composition for the layer shown in (d) is estimated from Fig. 2, since no room temperature photoluminescence was observed from the epilayer.

Figure 5 Surface morphology of $\mathrm{Ga}_{1-x} \operatorname{In}_{x} \mathrm{As}_{y} \mathrm{Sb}_{1-y}$ epilayers grown at $525^{\circ} \mathrm{C}$ on $(100) 2^{\circ}$ toward (110) GaSb.

Figure 6 Double crystal $x$-ray diffraction of $\mathrm{Ga}_{3-x} \operatorname{In}_{x} \mathrm{As}_{y} \mathrm{Sb}_{1-y}$ epilayers grown at $525^{\circ} \mathrm{C}$ on (100) $6^{\circ}$ toward (111)B GaSb substrates with In compositions: $(a) x=0.09, y=$ $0.08 ;$ (b) $x=0.16, y=0.15 ;$ (c) $x=0.20, y=0.18$.

Figure 7 Photoluminescence spectra measured at 4 and $300 \mathrm{~K}$ of $\mathrm{Ga}_{1-x} \mathrm{In}_{\mathrm{x}} \mathrm{As}_{\mathrm{y}} \mathrm{Sb}_{1-\mathrm{y}}$ grown on (100) $6^{\circ}$ toward (111)B GaSb substrates. Layers were grown at $525^{\circ} \mathrm{C}$ : (a) $\mathrm{x}=$ $0.16, y=0.15 ;(b) x=0.20, y=0.18$.

Figure 8 Photoluminescence full width at half-maximum measured at $4 \mathrm{~K}$ of GaInAsSb layers grown on $\mathrm{GaSb}$ substrates at $525^{\circ} \mathrm{C}$ (open squares), $550^{\circ} \mathrm{C}$ (solid circles), and $575^{\circ} \mathrm{C}$ (open circles).

Figure 9 Difference between 4 and $300 \mathrm{~K}$ photoluminescence peak energy as a function of 4 $\mathrm{K}$ peak energy. Layers were grown at $525^{\circ} \mathrm{C}$ (open squares), $550^{\circ} \mathrm{C}$ (solid circles), and $575^{\circ} \mathrm{C}$ (open circles).

Figure 10 Electrical properties measured at $300 \mathrm{~K}$ of (a) p-Ga0.87In0.13Aso.12Sbo.88 and (b) n-

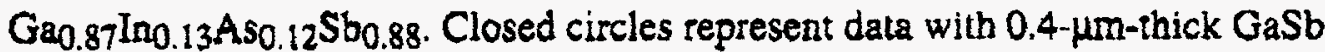
buffer layer. Open circle for 0.8 - $\mu \mathrm{m}$-thick buffer layer.

Figure 11 External quantum efficiency of several TPV devices as a function of wavelength.

Figure 12 Open circuit voltage as a function of short circuit current density. 


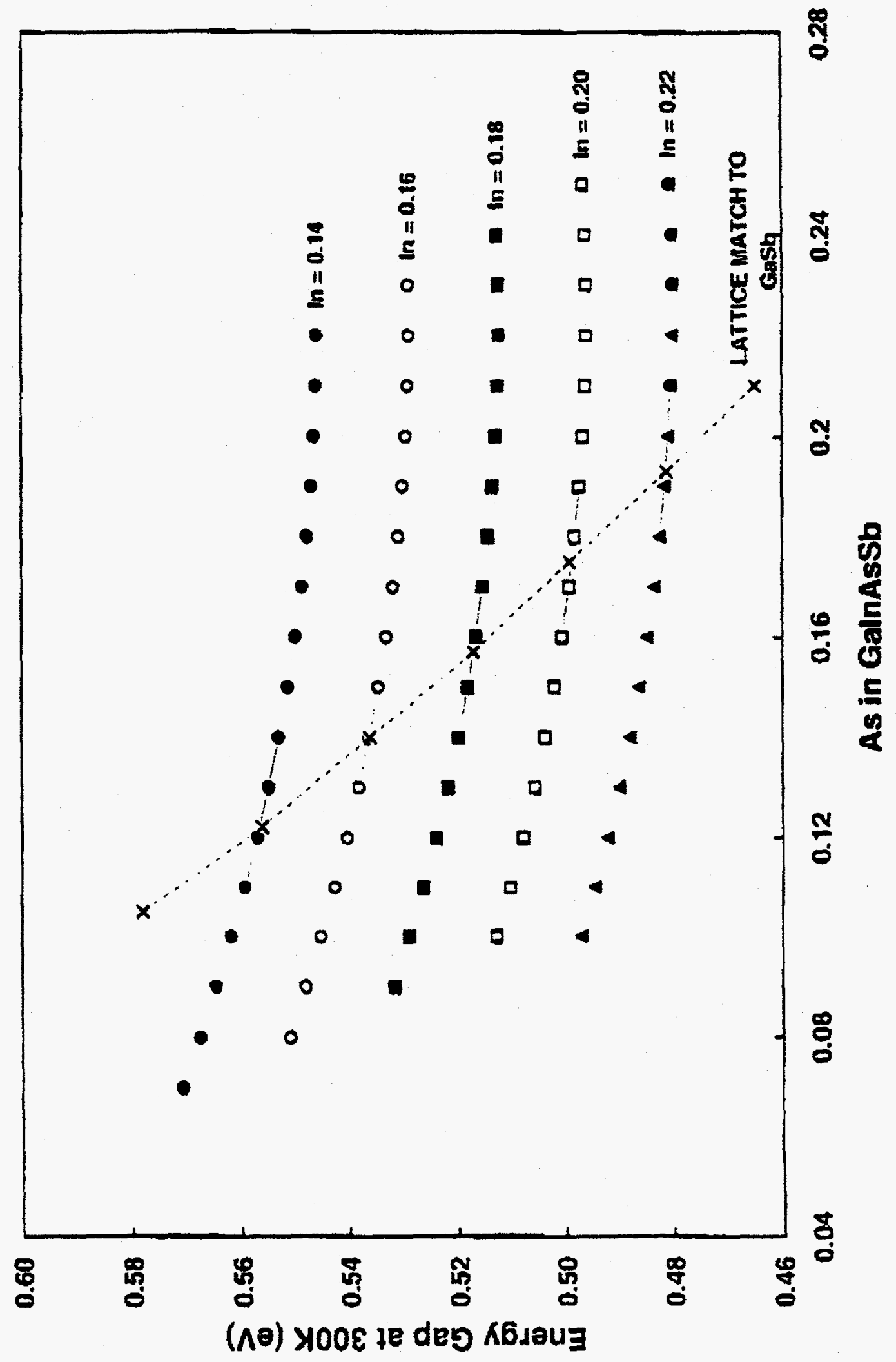




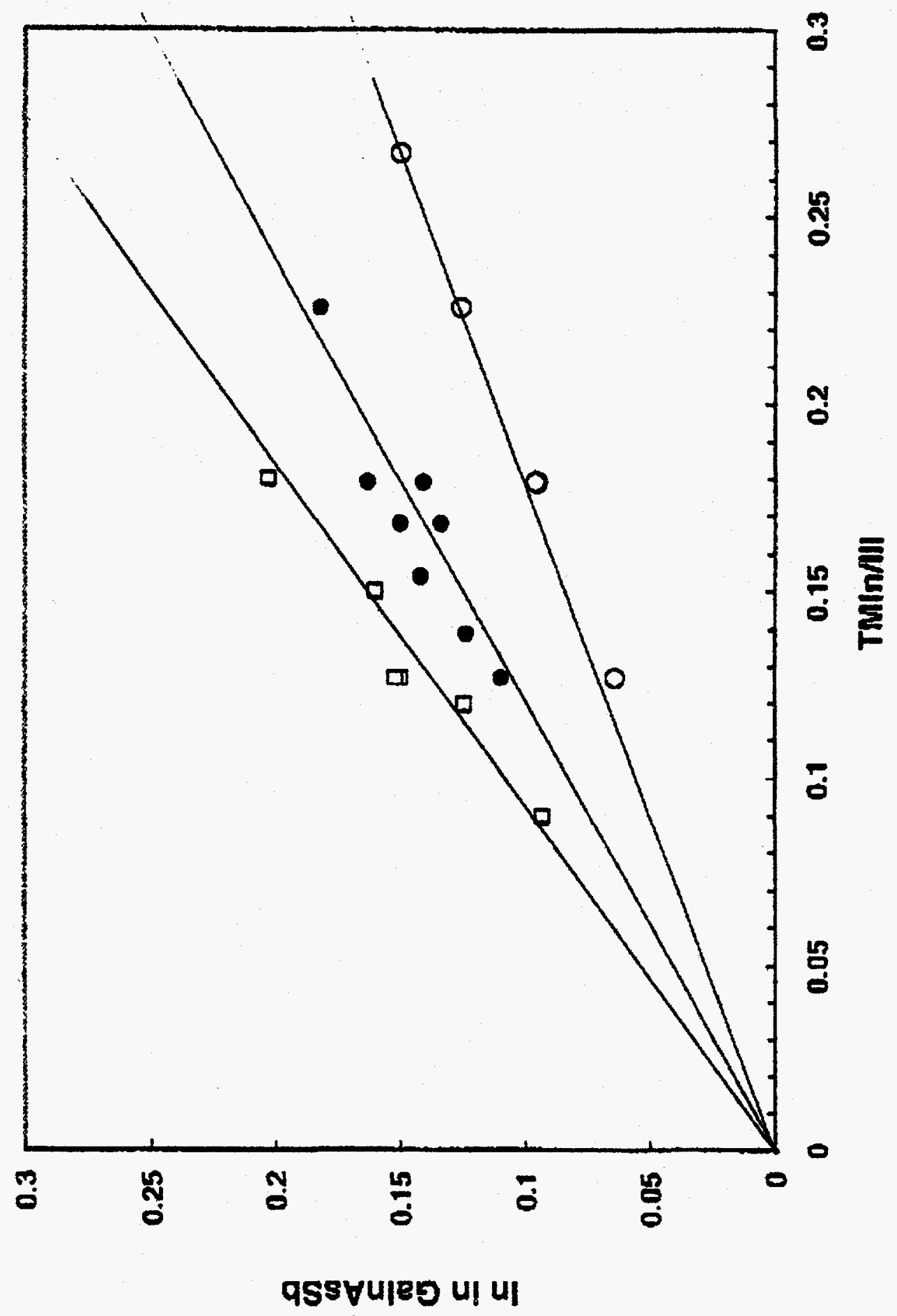




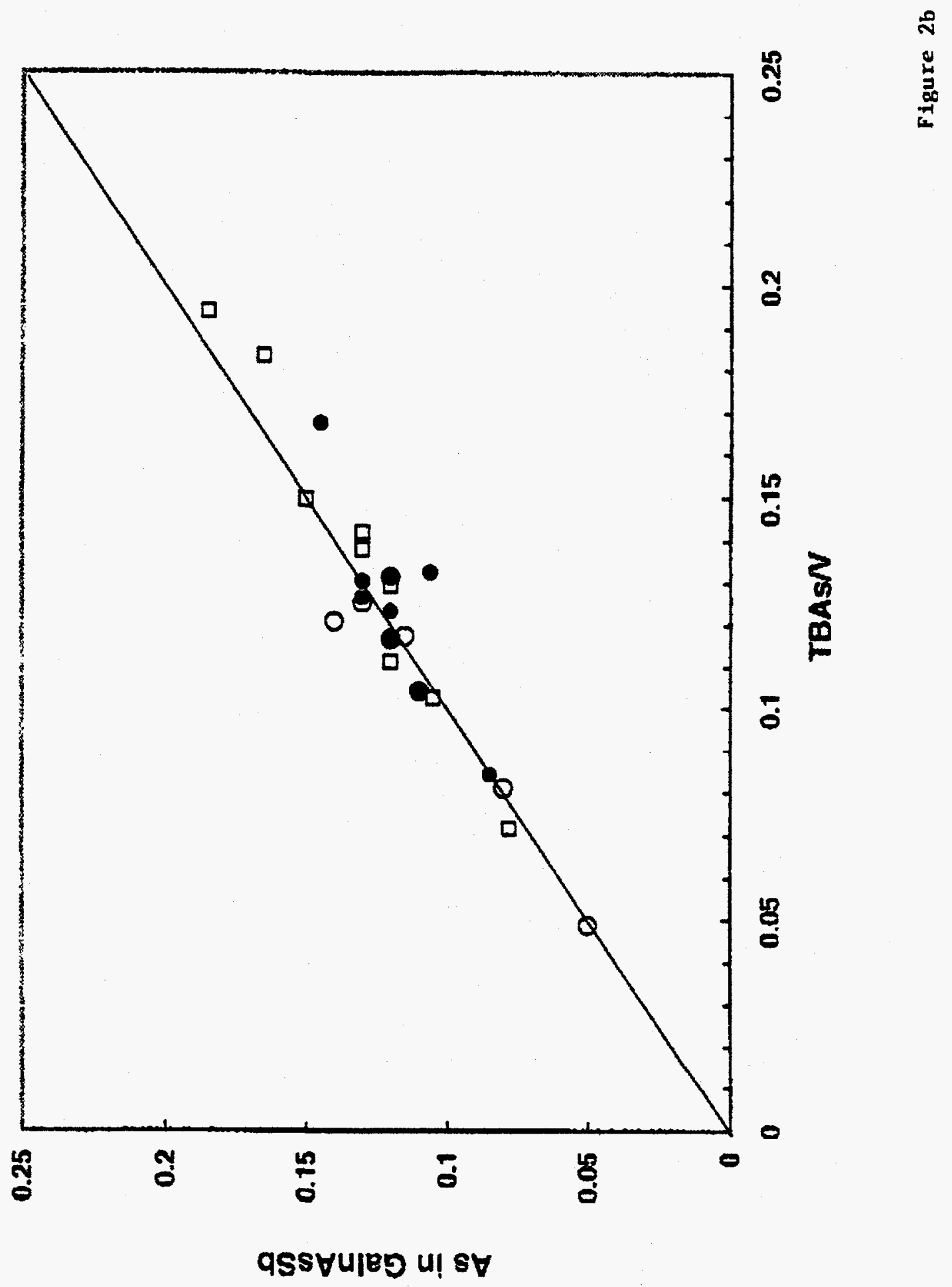




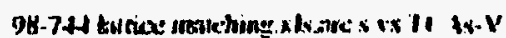

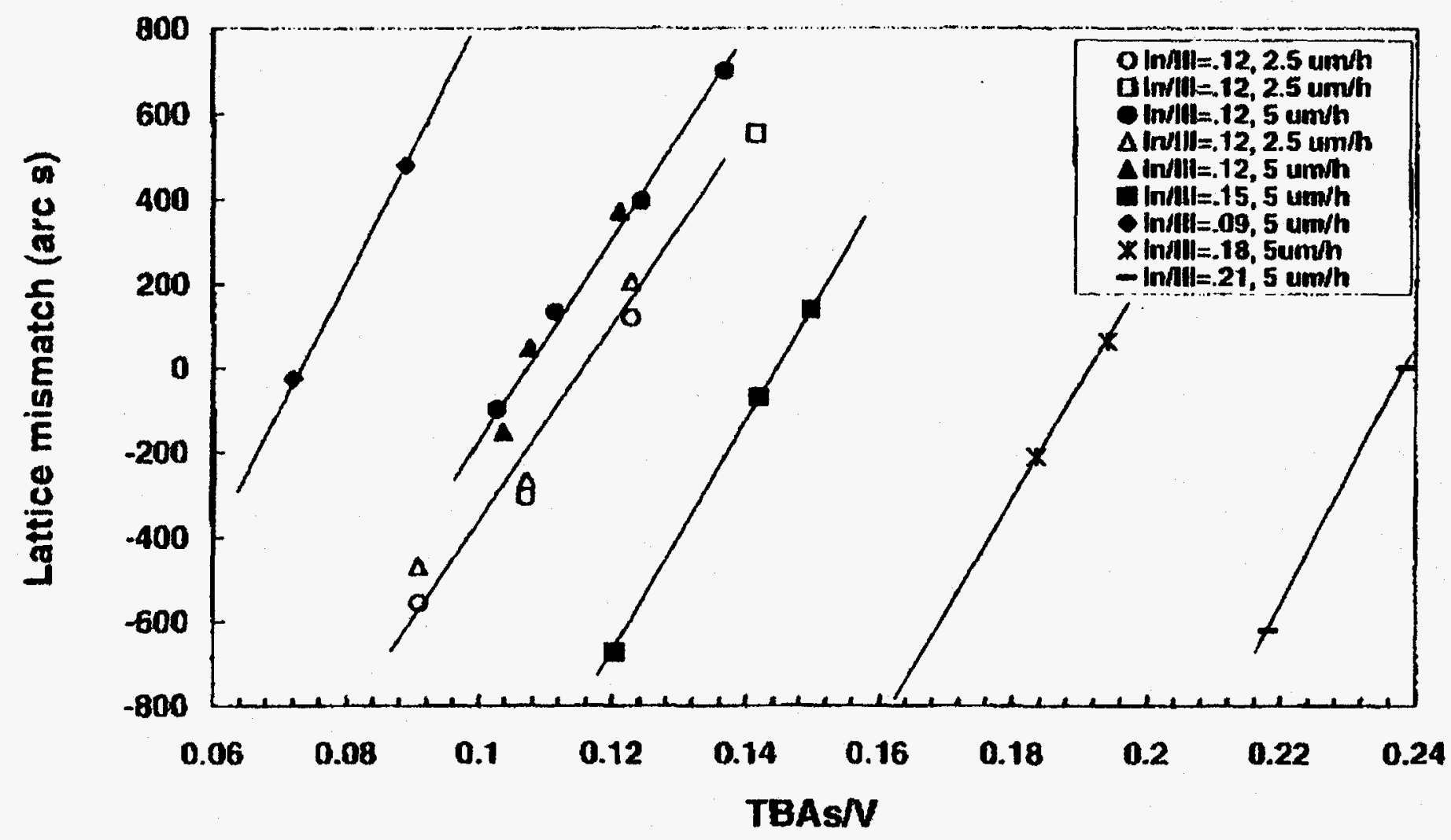

$\stackrel{0}{\circ}$

Figure 3 

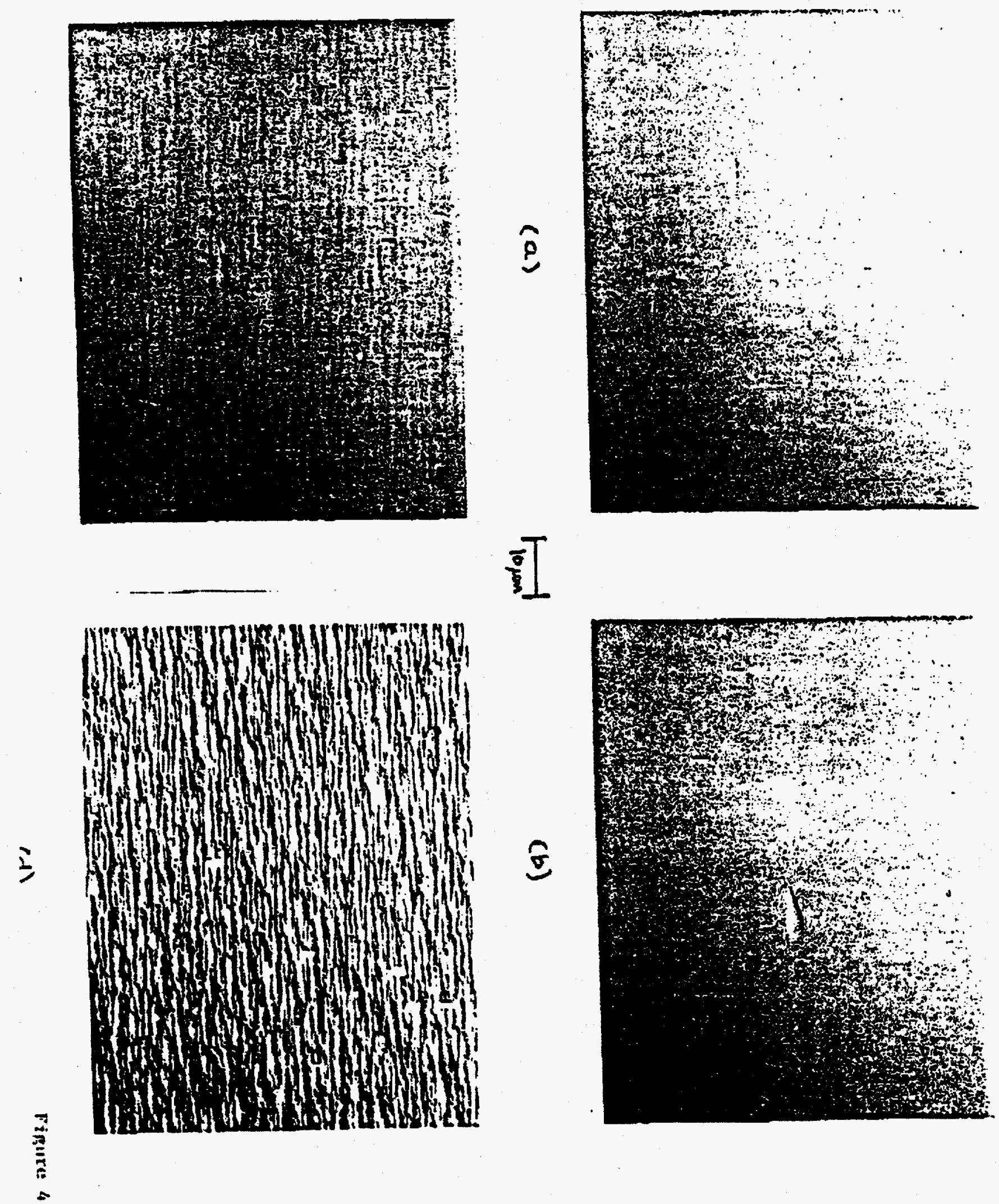
ร อมกริ

wriol

$\longrightarrow$

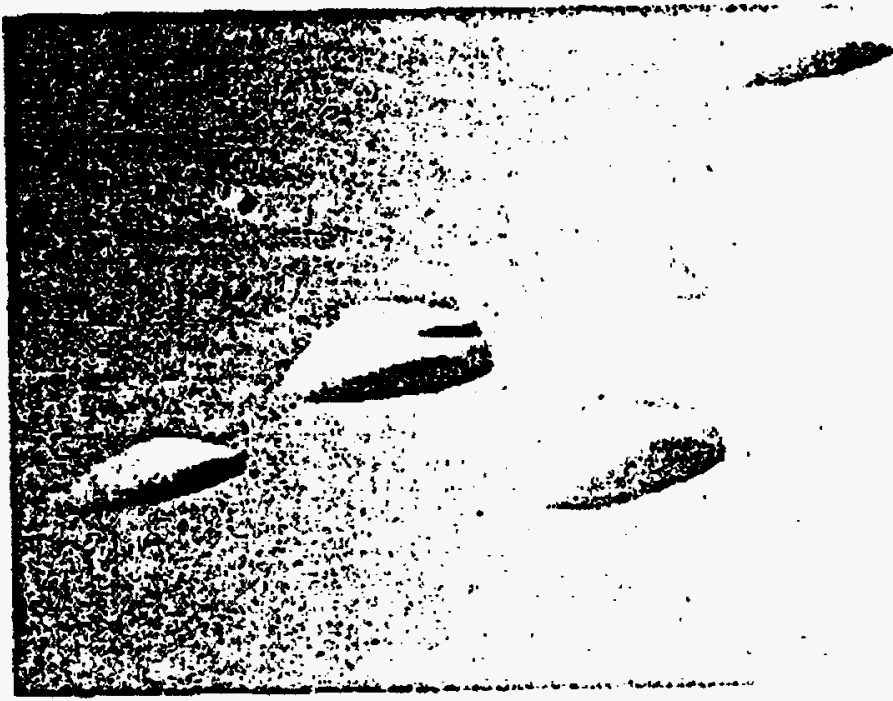




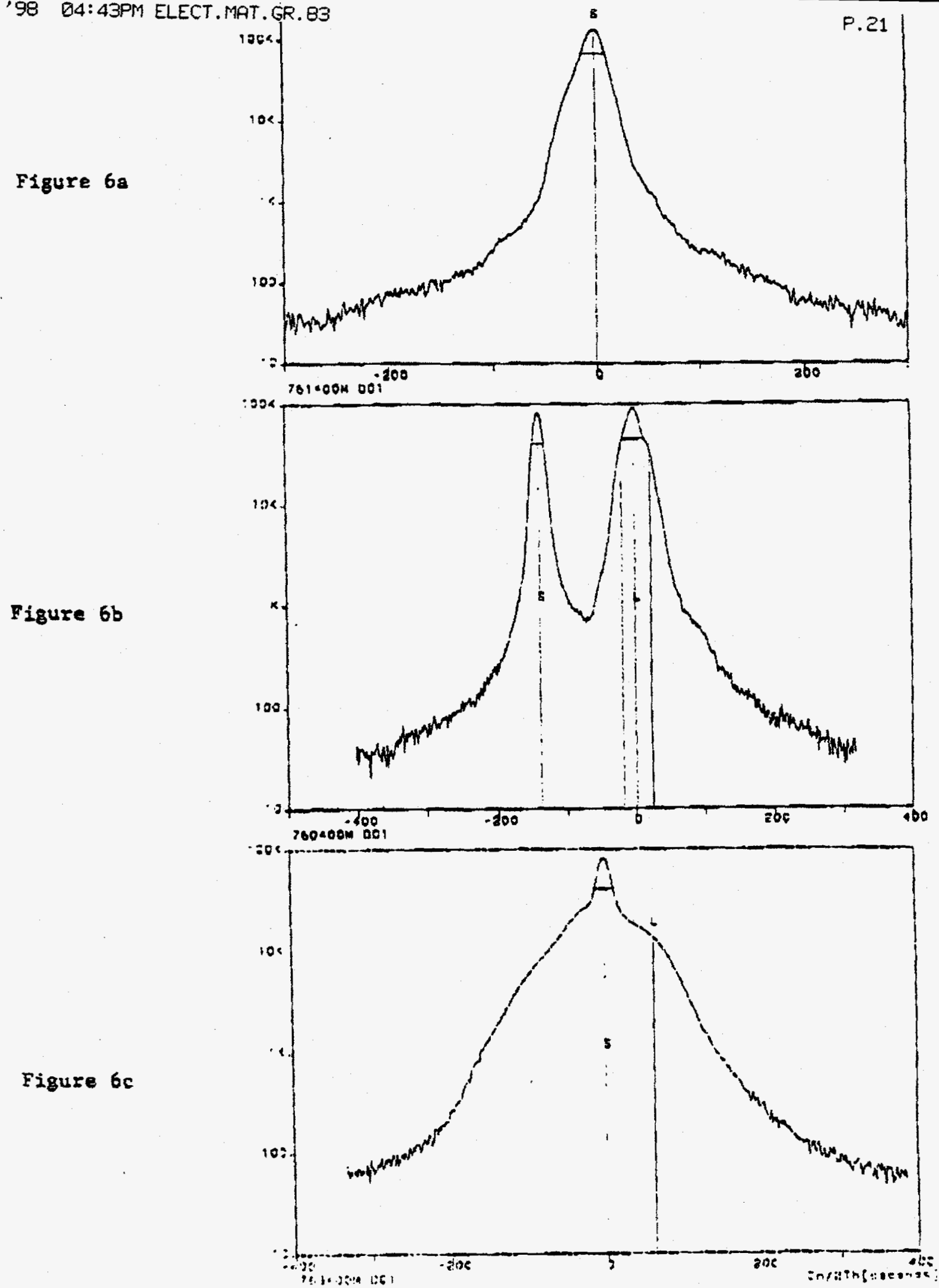




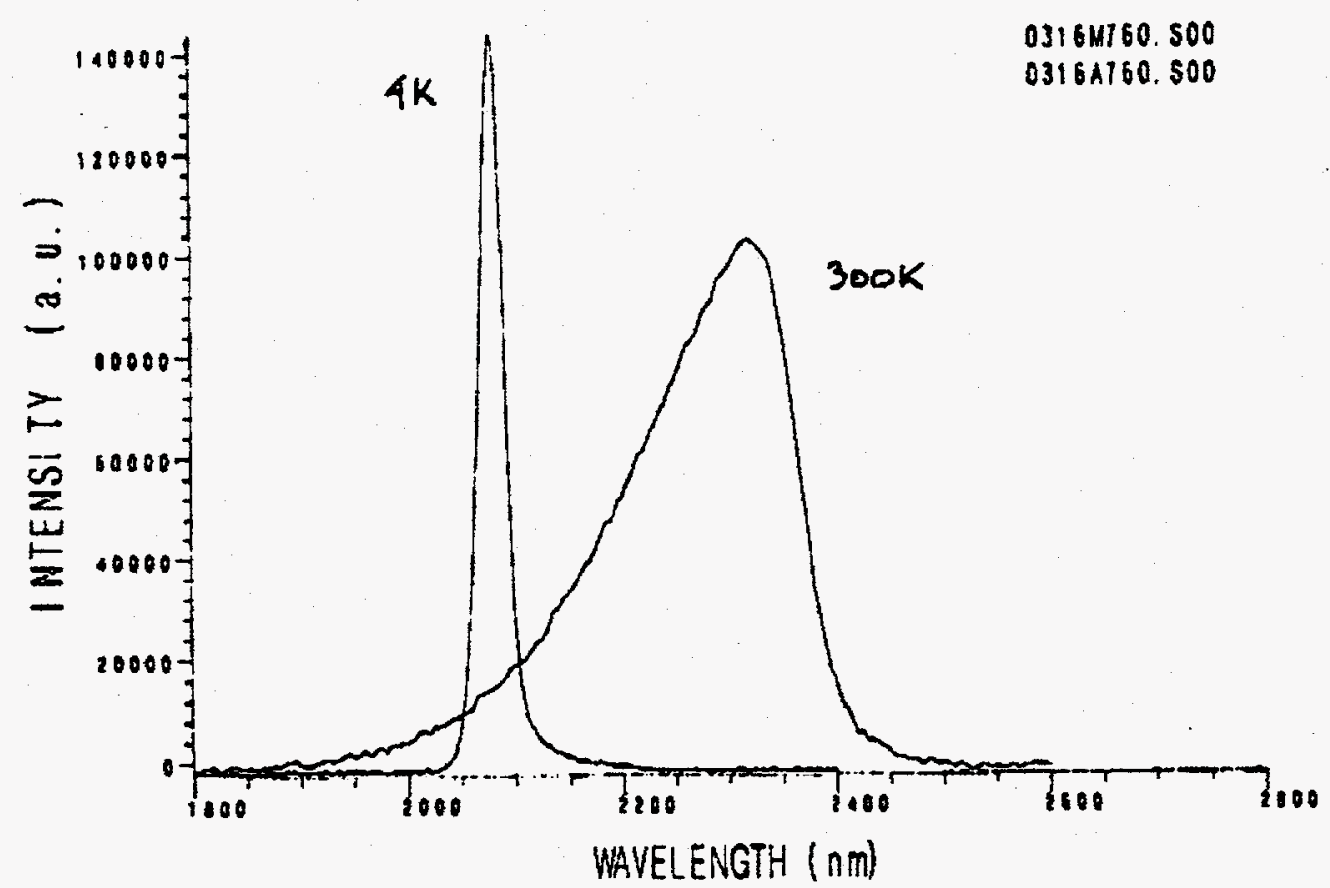

(a)

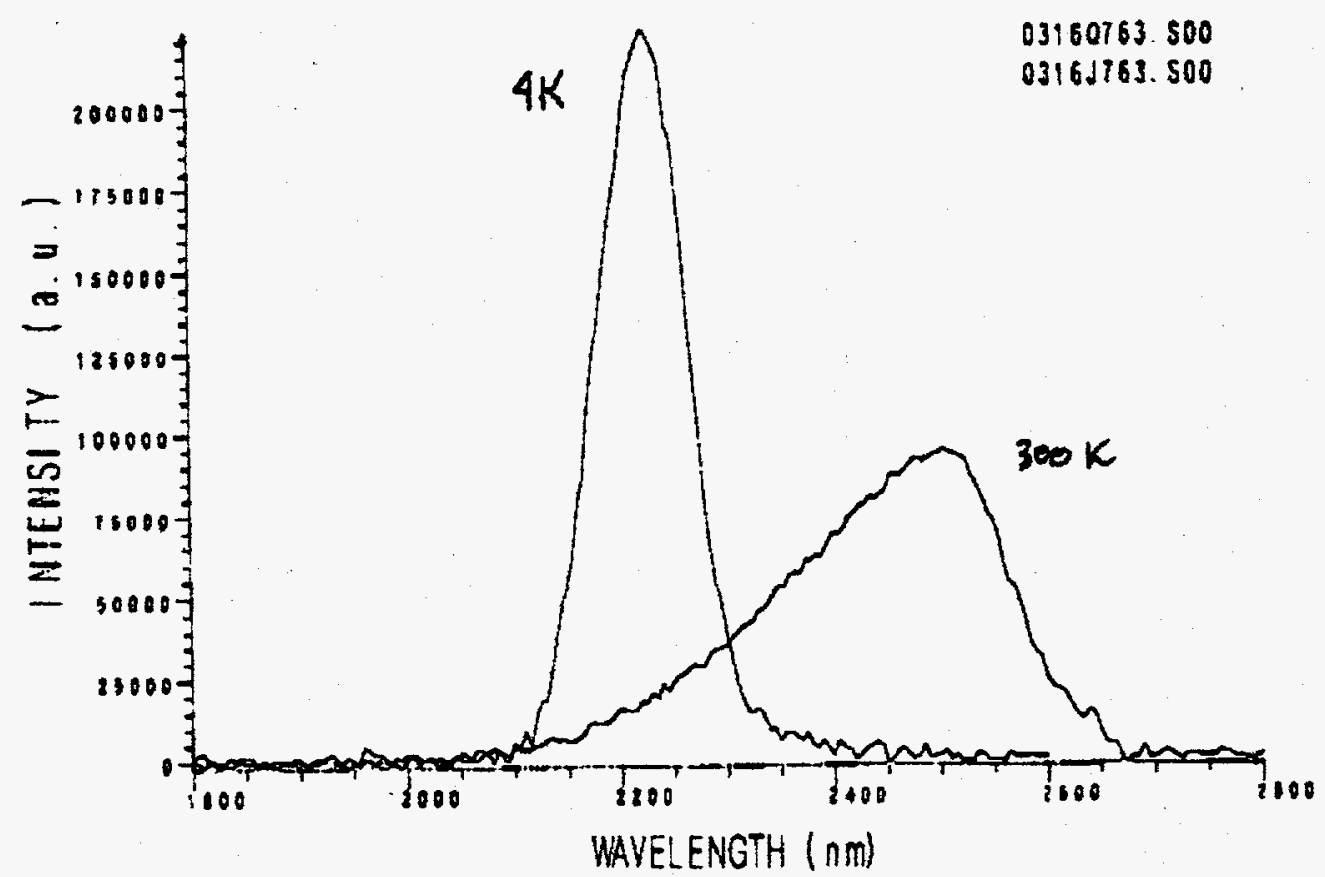

(b) 


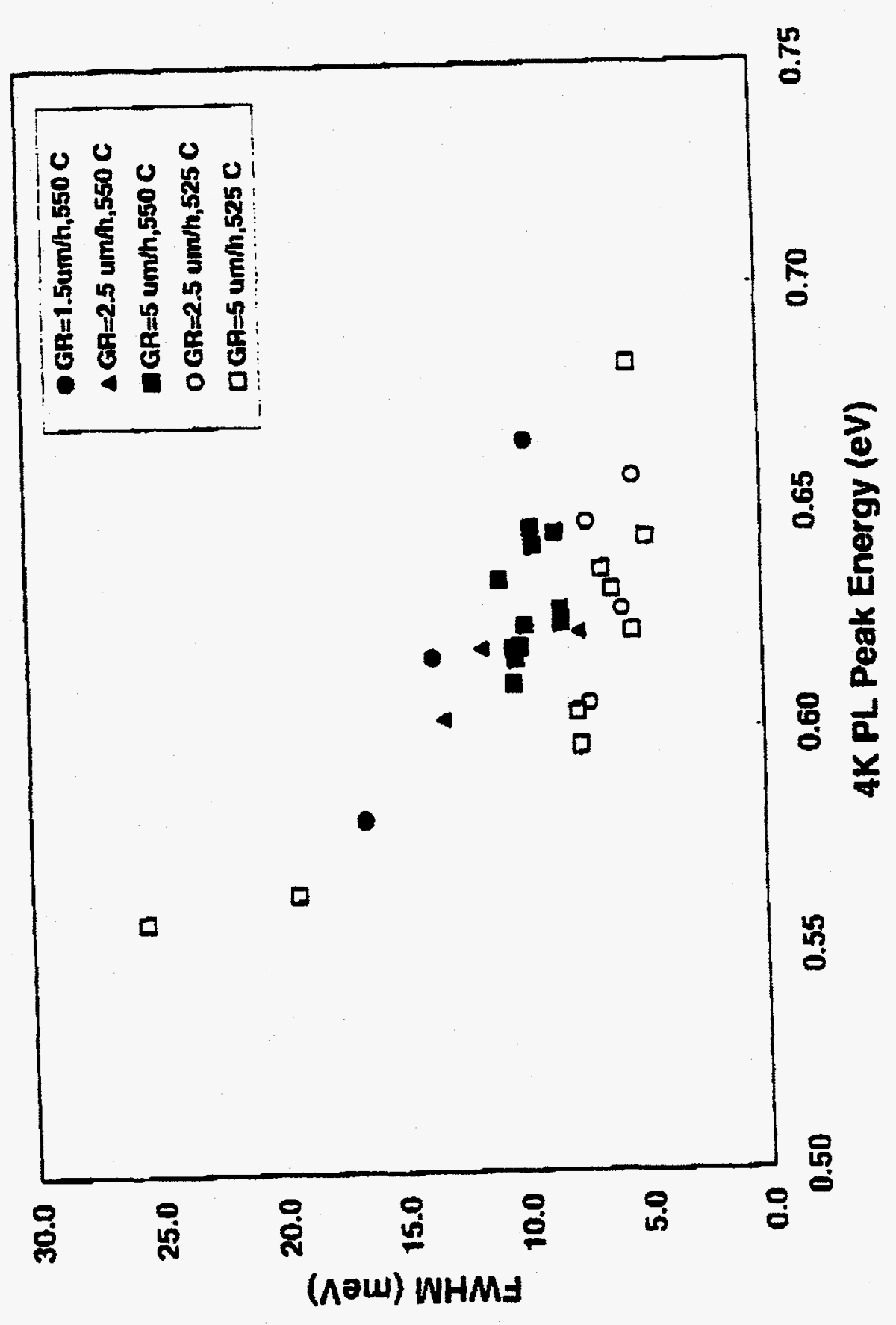




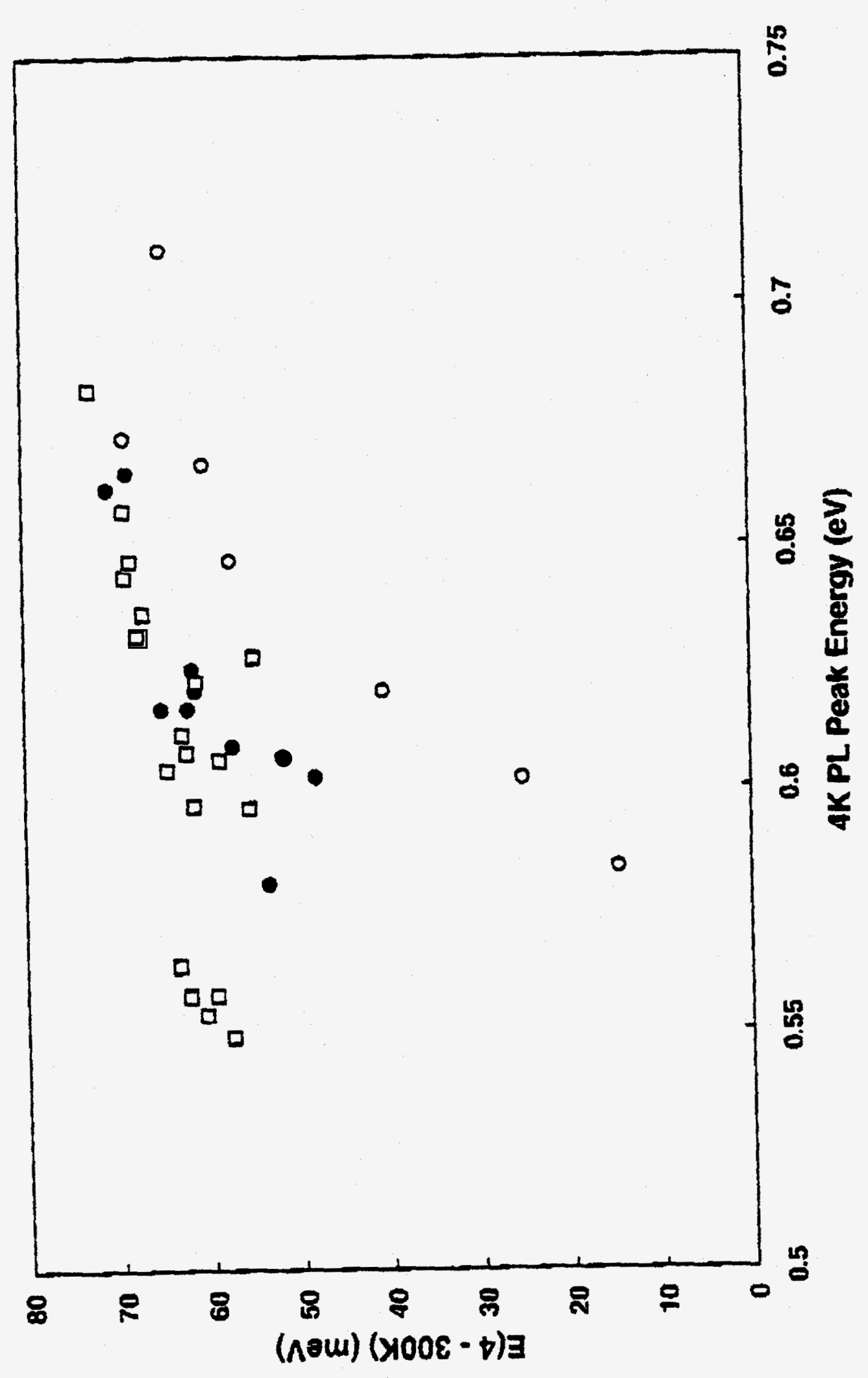




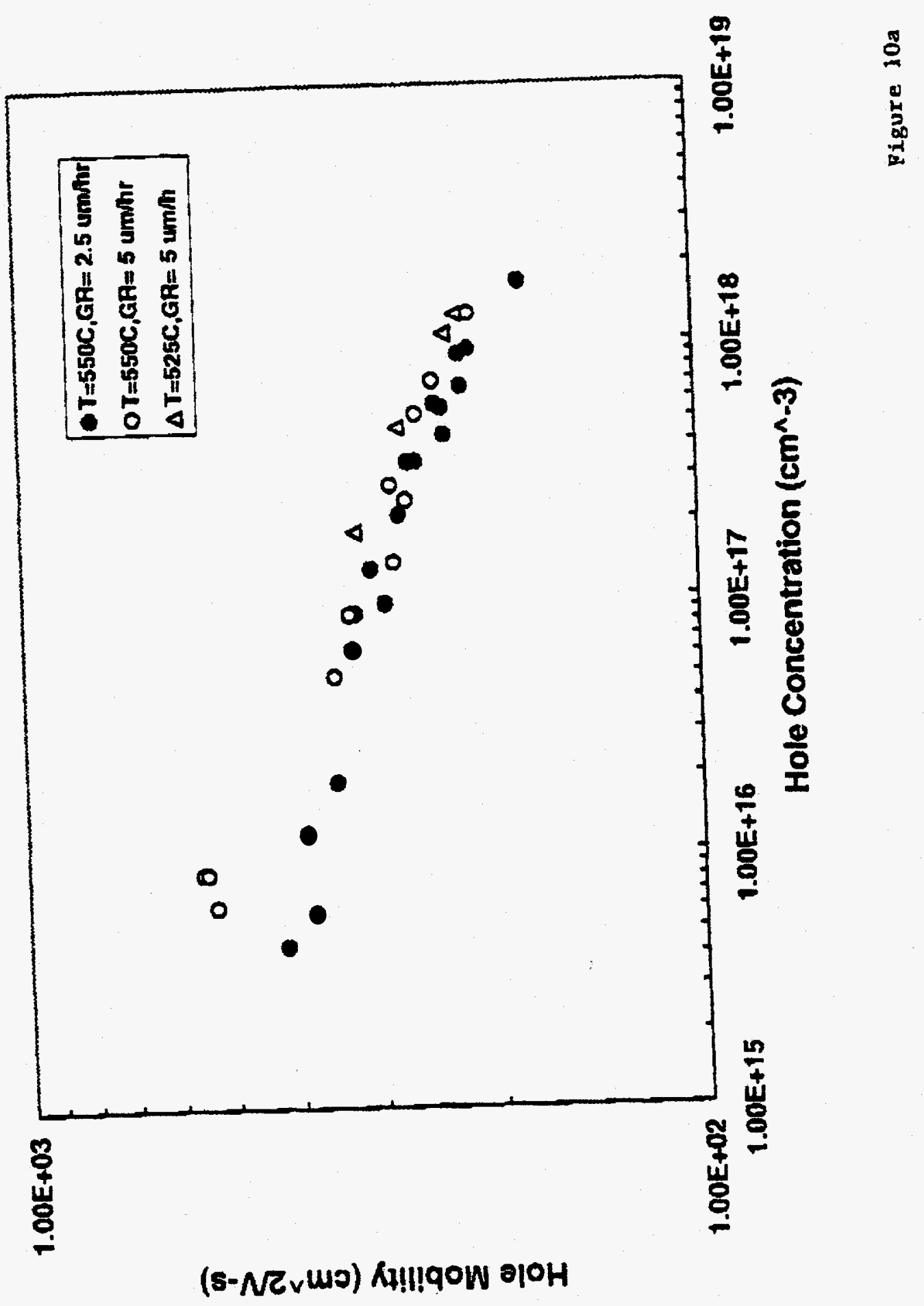




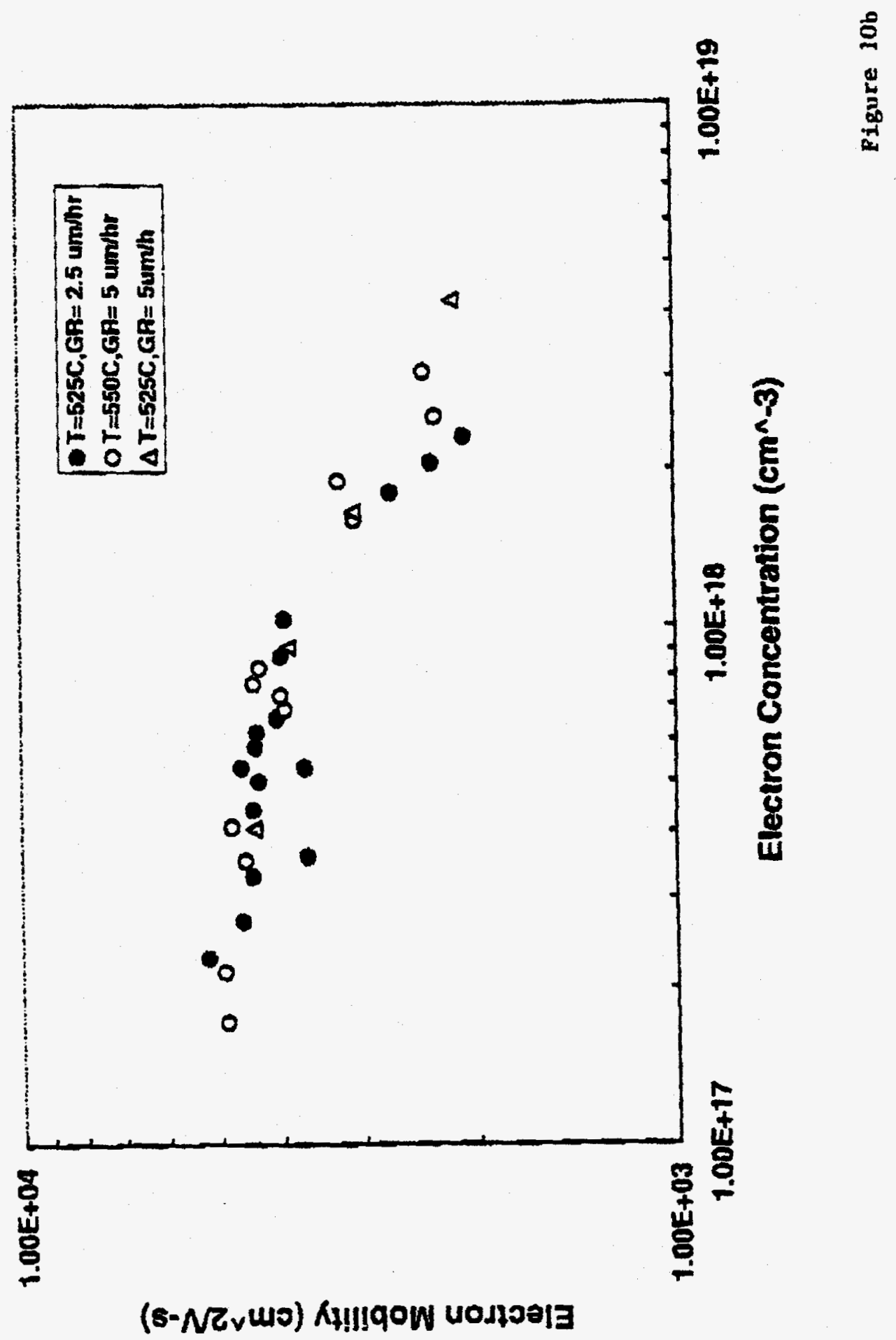




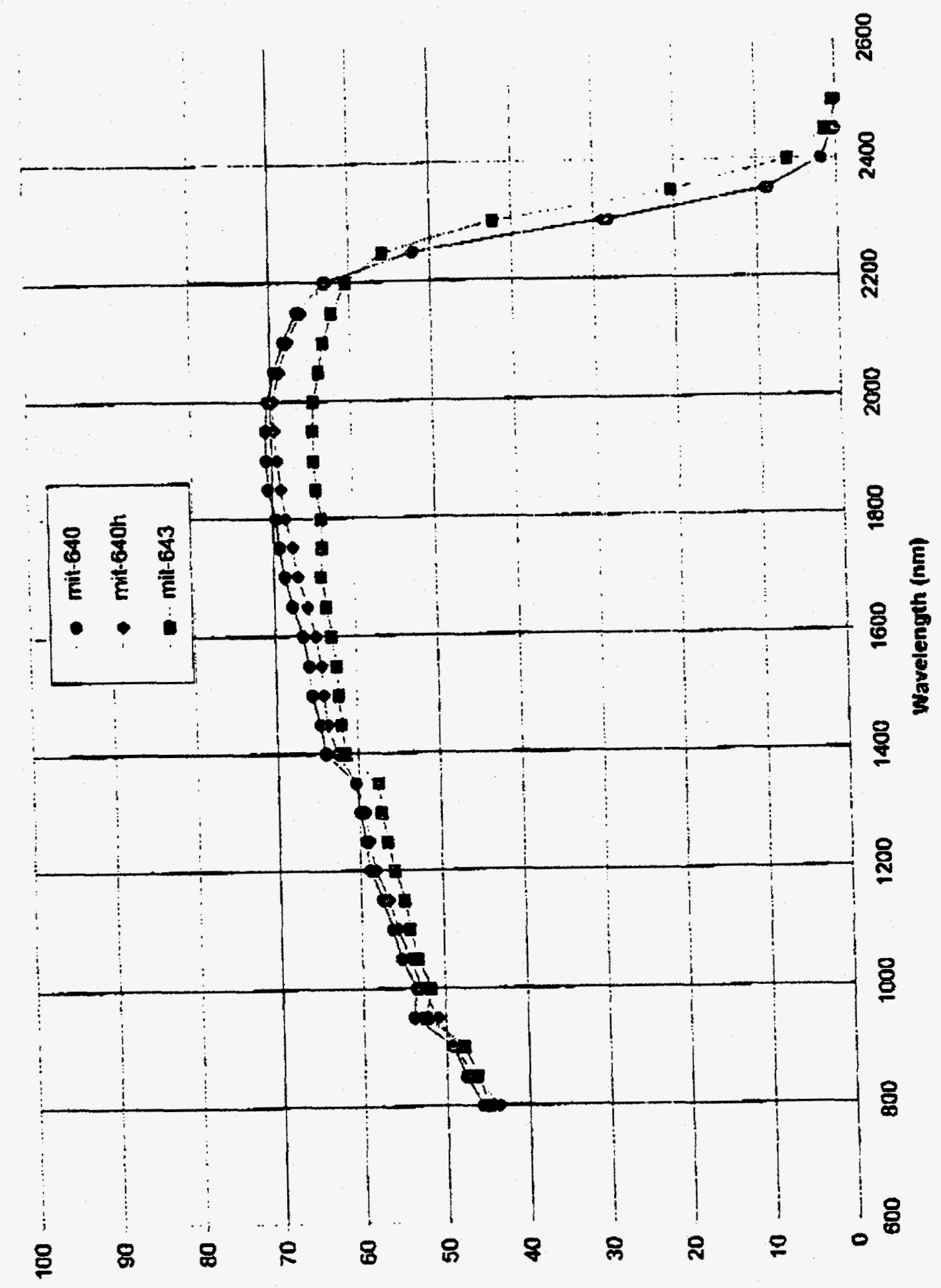

$(\%)$ Jo leusajx] 


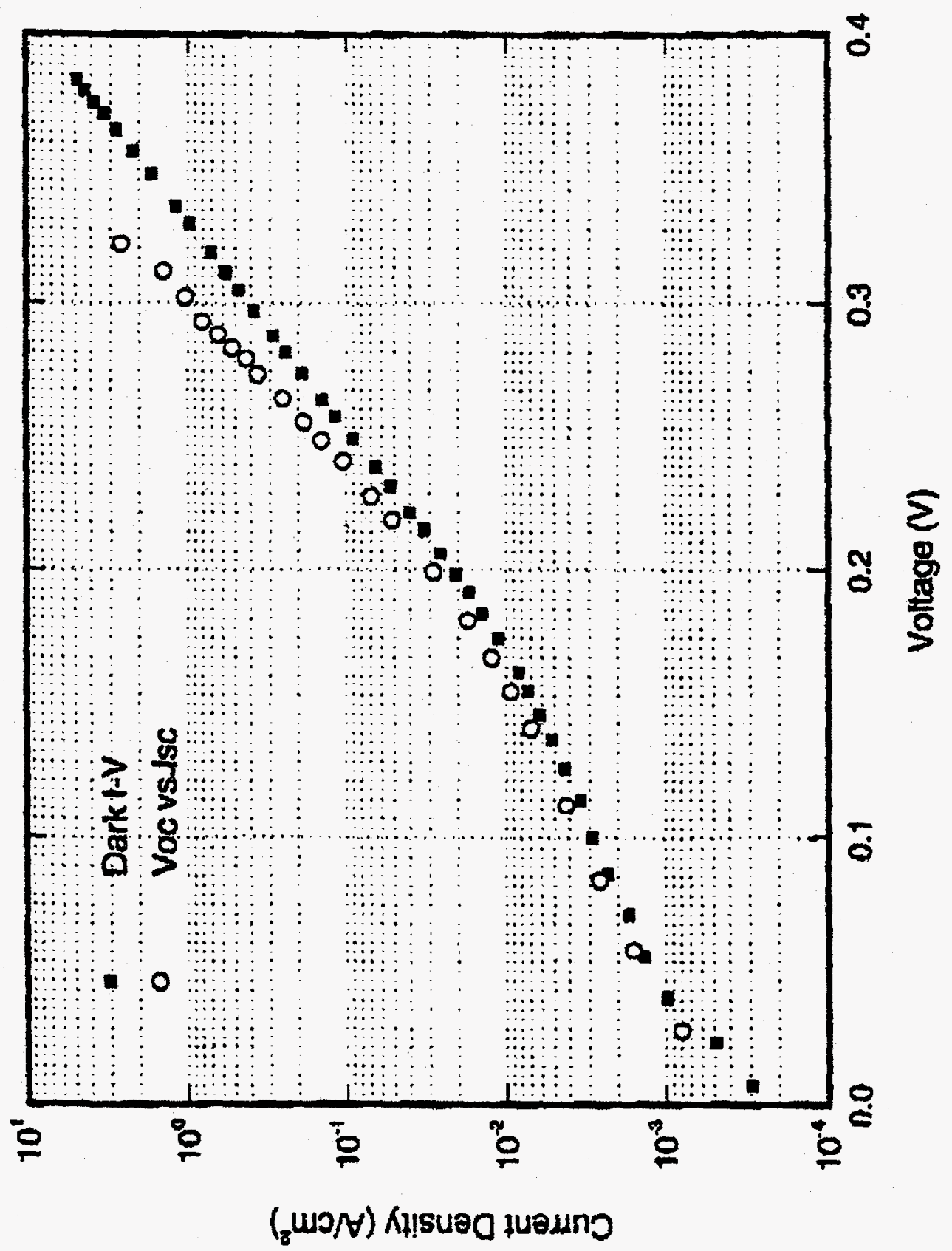

